\title{
The Effect of Fhb1 and Fhb5 Quantitative Trait Loci in Hard Red Spring Wheat Does Not Depend on Fungicide Use for Managing Fusarium Head Blight in Wheat
}

\author{
Gurcharn S. Brar, ${ }^{1, \dagger}$ Garry Hnatowich, ${ }^{2}$ Gary Peng, ${ }^{3}$ Pierre J. Hucl, ${ }^{1}$ and Hadley R. Kutcher ${ }^{1}$ \\ ${ }^{1}$ Crop Development Centre, Department of Plant Science, University of Saskatchewan, Saskatoon, Saskatchewan S7N 5A8, \\ Canada \\ ${ }^{2}$ Irrigation Crop Diversification Corporation, Outlook, Saskatchewan SOL 2NO, Canada \\ ${ }^{3}$ Saskatoon Research and Development Center, Agriculture and Agri-Food Canada, Saskatoon, Saskatchewan S7N 0X2, Canada
}

\begin{abstract}
Fusarium head blight (FHB), caused by Fusarium graminearum, is one of the most damaging diseases that affect wheat in Canada. The disease is best managed by integrating host resistance and fungicides, mainly demethylation inhibitors. Research has shown that the effect of fungicides may be dependent on the level of resistance of the cultivar. However, whether the performance of genotypes carrying specific Sumai 3-derived major FHB quantitative trait loci is dependent on fungicide application has not been explored. In our study, the performance of near-isogenic lines (NILs; $<1.0 \%$ genome/alleles from the resistance donor), carrying Fhbl and Fhb5 in a hard red spring wheat cultivar CDC Go background compared with a

were conducted at five site-years in Saskatchewan, Canada, between 2016 and 2017. In both the individual and combined analysis (all trials), we found that the effect of NILs and metconazole in suppressing FHB symptoms and deoxynivalenol (DON) accumulation in the grain was additive. FHB severity was generally low and fungicide efficacy levels, relative to the untreated control, were increased in the MS cultivar than in the NILs carrying Fhb1 and Fhb5, which were least affected by the disease. The results confirm the importance of integrating fungicides with cultivar resistance to reduce FHB and DON, regardless of the presence of those well-characterized resistant genes.
\end{abstract} moderately susceptible (MS) genotype, was evaluated with and without one application of metconazole during full flowering. Field experiments
Keywords: Fhb2, Fusarium-damaged kernels, scab
Fusarium head blight (FHB), also known as scab, is a fungal disease of small grain cereal crops such as wheat, barley, oats, rye, and annual canarygrass (Cholango-Martinez et al. 2016; McMullen et al. 2012). The disease can be caused by several Fusarium spp., but members of the $F$. graminearum species complex are the most frequent FHB pathogens worldwide (van der Lee et al. 2015). The economic impact of those epidemics is discussed in great detail in a feature article by McMullen et al. (1997). This spike disease of small grain cereals results in yield as well as quality loss and causes seedling blight if infected seed is sown the next year (Gilbert and Haber 2013). Despite extensive research, FHB remains an important disease of wheat in Canada and worldwide, and the resulting toxins are the most dangerous consequence of FHB epidemics.

FHB is best managed by the integration of cultural, chemical, and host resistance (Amarasinghe et al. 2013; Blandino et al. 2012; Scala et al. 2016; Wegulo et al. 2011; Willyerd et al. 2012). However, until the past few years there was limited choice and availability of moderately resistant (MR) cultivars and even today, the majority of the cultivars in western Canada (and elsewhere) are only moderately susceptible (MS) or intermediate (I) in resistance (Saskatchewan Seed Growers Association 2018). In the Canadian context, FHB is the most challenging disease to manage among five Priority One diseases (for which at least an intermediate level of resistance is recommended in

\section{${ }^{\dagger}$ Corresponding author: G. S. Brar; gurcharn.brar@usask.ca}

Funding: G. S. Brar acknowledges financial support from a University of Saskatchewan Dean's PhD Scholarship, a Saskatchewan Wheat Development Commission Scholarship, and the Monsanto Beachell-Borlaug International Scholars Program for PhD program funding. The authors and/or University of Saskatchewan do not promote or advertise any of the fungicide products mentioned in this manuscript/research.

The author(s) declare no conflict of interest.

Accepted for publication 5 February 2019.

(c) 2019 The American Phytopathological Society commercial cultivars), as leaf and stem rusts and common bunt is well managed as a result of long-term breeding efforts and stripe rust is epidemic only sporadically (Brar et al. 2018). Cultivars with differential resistance are mainly in hexaploid wheat, whereas all durum cultivars in North America are mainly susceptible or MS. Crop rotations have become a less common practice by growers, owing to limited choices of nonhost crops, large farm sizes, and economic reasons (Beres et al. 2018). Fungicides have increased in use by wheat growers since the early 1990 s, especially those of the demethylation inhibitor (DMI) group (e.g., triazoles) (Boyacioglu et al. 1992; Cools et al. 2013; McMullen et al. 2012; Paul et al. 2008). Compared with single site-specific fungicides (e.g., quinone outside inhibitors [QoIs]), which can be rendered ineffective because of single point mutations in the pathogen, DMIs are generally considered to have a lower risk for resistance (Cools et al. 2013). In addition, DMIs are preferred over QoIs because some of the latter may lead to increased deoxynivalenol (DON) levels in the grain (Amarasinghe et al. 2013; Bissonnette et al. 2018; Paul et al. 2018; Ye et al. 2017). Among the DMIs, metconazole, prothioconazole, and tebuconazole plus prothioconazole would offer the most effective FHB and DON reduction (Paul et al. 2008). The greater efficacy of metconazole and prothioconazole plus tebuconazole in reducing the FHB index and DON was confirmed in a quantitative summary of almost 2 decades of fungicide trials conducted in the United States (Paul et al. 2018).

Few studies have focused on the effect of multiple strategies to manage FHB in wheat, particularly the combination of host resistance and fungicide application (Amarasinghe et al. 2013; McMullen et al. 2012; Mesterházy et al. 2003; Scala et al. 2016; Wegulo et al. 2011; Willyerd et al. 2012; Ye et al. 2017). Significant cultivar-byfungicide interaction has been reported but very few of the studies used cultivars carrying any known resistance genes/quantitative trait loci (QTLs). FHB-resistant cultivars with identified QTLs or genes were only available in the early 2010s; most studies focused on fungicide efficacy (FE) on single or multiple cultivars with only small differences in FHB resistance/tolerance. Some of the MR cultivars in North America derive their resistance from Sumai 3 or its derivatives and carry Fhb1, Fhb2, Fhb5, and/or minor QTLs. The use of 
Sumai 3-derived resistance in modern cultivars has increased considerably in breeding programs (reviewed in Bai et al. 2018; Gilbert and Haber 2013; McMullen et al. 2012). The availability of breederfriendly and robust molecular markers for $F h b 1$ has helped to introgress this gene into elite wheat germplasm (Liu et al. 2008; Rawat et al. 2016). Fhbl was introgressed into 16 locally adapted hard winter wheat cultivars and breeding lines from five states in the United States (Bai et al. 2018). Results of some studies that investigated the interaction effect of host resistance and fungicides were inconsistent and the resistance genes/QTLs in these cultivars were unknown (Blandino et al. 2012; Scala et al. 2016; Wegulo et al. 2011). Based on the reviewed literature, we hypothesized that the Sumai 3-derived major QTLs/genes Fhbl and Fhb5 do not affect fungicide performance in spring wheat. The objective of the present study was to investigate whether the effect of genotypes carrying wellcharacterized FHB resistance genes is dependent on the application of metconazole in FHB control. Near-isogenic lines (NILs) carrying $F h b 1, F h b 2$, and $F h b 5$ in the same genetic background were used in order to account for the effects resulting from these introgressed genes.

\section{Materials and Methods}

Plant material. Six wheat lines, consisting of CDC Go (the recurrent parent of NILs and MS check, respectively), Carberry (Fhb1, Fhb5 plus unknown QTL; MR check), CDC Go NIL-2 (Fhb1, Fhb5), CDC Go NIL-21 (Fhb5), CDC Go NIL-28 (Fhb1, Fhb2, and Fhb5), and CDC Go NIL-38 (Fhb1), were used in the study. CDC Go (pedigree: Grandin/SD3055) and Carberry (pedigree: Alsen/Superb) are hard red spring wheat cultivars, registered for cultivation in western Canada (DePauw et al. 2011; P. J. Hucl, unpublished data). The NILs were developed from the crosses CDC Go*4/04GC0139 by the single-seed descent method. Line 04GC0139 (pedigree: ND2710/RL4851//BW278) was provided by Dr. Julian Thomas (retired, Cereal Research Centre, Agriculture and Agri-Food Canada, Winnipeg, MB, Canada) and carries Fhb1, Fhb2, and Fhb5 genes (Brar et al. 2019a). Line 04GC0139 has ND2710 and BW278 (pedigree: AC Domain*2/Sumai 3 ) in its pedigree, which are both derivatives of Suami 3. During NIL development, $F_{1}$ donors for each backcross cycle were screened with microsatellite markers for markerassisted selection as follows: umn10 for Fhbl (Liu et al. 2008), gwm133 and gwm644 for Fhb2 (Cuthbert et al. 2007), and gwm304, gwm293, barc117, and wmc705 for Fhb5 (Xue et al. 2011).
NIL genotyping. The original crosses were made to develop NILs carrying combinations of Fhb1, Fhb2, and Fhb5 in the CDC Go background, and microsatellite markers flanking these QTL regions were utilized for marker-assisted selection. To confirm the presence of these QTL regions, NILs were genotyped further with the following molecular markers: umn10, gwm493, and gwm533, functional markers for the pore-forming toxin (PFT) protein associated with Fhbl (Liu et al. 2008; Rawat et al. 2016), as well as single nucleotide polymorphism (SNP) markers from Zhao et al. (2018); gwm304, barc117, wmc705, gwm415, gwm293, barc180, barc186, and SNPs from Buerstmayr et al. (2018) for Fhb5; and gwm644, CAPS3, and SNPs from Zhao et al. (2018) for Fhb2. In addition, NILs were also genotyped using a wheat $90 \mathrm{~K}$ iSelect SNP genotyping assay $(90 \mathrm{~K}$, hereafter) following the protocol described by Wang et al. (2014). Briefly, SNP alleles were called using GenomeStudio (Illumina Inc., San Diego, CA) and filtered based on polymorphisms between parents. All SNP markers from the wheat $90 \mathrm{~K}$ assay were physically positioned on the Chinese Spring wheat reference genome sequence. The SNP-bearing sequences were probed to the entire bread wheat NRGene genome assembly RefSeq version 1.0 (International Wheat Genome Sequencing Consortium, https://wheat-urgi.versailles.inra.fr/ Seq-Repository/Assemblies) using an in-house Basic Local Alignment Search Tool portal.

Study sites and experimental conditions. The experiment was conducted in field plots near Saskatoon and Outlook (2016) and Saskatoon, Melfort, and Outlook (2017) for a total of five site-years. However, the Saskatoon site (2017) was abandoned as a result of negligible disease pressure of FHB. Details on seeding, inoculation, fungicide application, disease assessment, and harvest dates are provided in Table 1. Sprinkler irrigation was provided at Saskatoon over 4 weeks starting from early flowering to foster a conducive environment for disease development, whereas the Melfort trial was not irrigated. At the Outlook site, irrigation was applied through an overhead low-pressure system to keep the available soil moisture above $50 \%$. In 2016, because of above normal (155\% of normal) precipitation, only a single application of $12.5 \mathrm{~mm}$ was applied on 8 June 2016. In 2017, irrigation was applied six times (27 and 28 June 2017 and $6,10,18$, and 31 July 2017), targeting $12.5 \mathrm{~mm}$ for a single application and $75 \mathrm{~mm}$ for the whole growing season. The experiment was a randomized complete block design with four replications. The experiment had 12 treatment combinations consisting of six genotypes and two fungicide application treatments (applied or not applied). Corn (Zea mays L.) spawn inoculum (colonized by $F$. graminearum) was applied to the surface of all plots at all sites

Table 1. Description of study sites, soil type, seeding, inoculation, fungicide application, and disease rating dates, average monthly temperature and precipitation ${ }^{\mathrm{z}}$

\begin{tabular}{llll}
\hline & \multicolumn{1}{c}{ Saskatoon, SK } & \multicolumn{1}{c}{ Outlook, SK } & Melfort, SK \\
\hline Latitude and longitude & $52.24^{\circ} \mathrm{N} 106.67^{\circ} \mathrm{W}$ & $51.28^{\circ} \mathrm{N} 107.03^{\circ} \mathrm{W}$ & $52.51^{\circ} \mathrm{N} 104.36^{\circ} \mathrm{W}$ \\
Soil zone/series/texture & Black chernozemic loam & Dark brown & Moist black \\
Seeding date (2016/2017) & 19 May 2016 & 17 May 2016/18 May 2017 & $-/ 25 \mathrm{May} 2017$ \\
Inoculation date (2016/2017) & 30 June 2016 & 28 June 2016/7 July 2017 & $-/ 10$ July 2017 \\
Anthesis/fungicide application (2016/2017) & 10 July 2016 & 5 July 2016/10 July 2017 & $-/ 17$ July 2017 \\
Disease rating (2016/2017) & 2 August 2016 & 28 July 2016/3 August 2017 & $-/ 12$ August 2017 \\
\hline
\end{tabular}

${ }^{\mathrm{z}} \mathrm{SK}=$ Saskatchewan. Dashes indicate the trial was not conducted at Melfort in 2016.

Table 2. Proportion of the genome of each near-isogenic line (NIL) used in the study, from the recurrent parent CDC Go (A) and the resistant donor parent 04GC0139 (B), based on genome-wide single nucleotide polymorphism markers (90K Illumina iSelect assay) ${ }^{\mathrm{z}}$

\begin{tabular}{|c|c|c|c|c|c|c|c|c|c|c|c|c|}
\hline \multirow[b]{2}{*}{ Line } & \multicolumn{3}{|c|}{ Whole genome } & \multicolumn{3}{|c|}{$\begin{array}{l}\text { Chromosome 3B } \\
\text { (carrying Fhb1) }\end{array}$} & \multicolumn{3}{|c|}{$\begin{array}{l}\text { Chromosome 5A } \\
\text { (carrying Fhb5) }\end{array}$} & \multicolumn{3}{|c|}{$\begin{array}{l}\text { Chromosome 6B } \\
\text { (carrying Fhb2) }\end{array}$} \\
\hline & $\mathbf{A}$ & B & $\mathbf{H} / \mathbf{U}$ & $\mathbf{A}$ & B & $\mathbf{H} / \mathbf{U}$ & $\mathbf{A}$ & B & $\mathbf{H} / \mathbf{U}$ & $\mathbf{A}$ & B & $\mathbf{H} / \mathbf{U}$ \\
\hline NIL-2 (Fhb1+Fhb5) & 99.3 & 0.68 & 0.03 & 99.1 & 0.86 & 0.05 & 94.0 & 5.93 & 0.06 & 99.8 & 0.08 & 0.11 \\
\hline NIL-21 (Fhb5) & 99.2 & 0.73 & 0.03 & 100 & 0.03 & 0 & 93.1 & 6.86 & 0.03 & 99.8 & 0.11 & 0.08 \\
\hline NIL-28 $(F h b 1+F h b 2+F h b 5)$ & 99.1 & 0.78 & 0.11 & 98.4 & 1.28 & 0.26 & 91.8 & 6.61 & 0.12 & 98.1 & 1.58 & 0.28 \\
\hline NIL-38 $(F h b 1)$ & 99.4 & 0.58 & 0.04 & 98.7 & 1.28 & 0.05 & 99.5 & 0.53 & 0 & 99.9 & 0.05 & 0.05 \\
\hline
\end{tabular}

${ }^{\mathrm{z}}$ Data are given in percentages. $\mathrm{H}$ and $\mathrm{U}$ represent heterozygous or unknown alleles, respectively. 
about 12 to 14 days prior to flowering at $5 \mathrm{~g} / \mathrm{m}^{2}$. Two isolates of $F$. graminearum, M9-07-1 (a 3-ADON chemotype; NRRL 52068) and M1-07-2 (a 15-ADON chemotype; NRRL 47847), were used for preparing corn spawn inoculum (Gilbert et al. 2014). The corn spawn inoculum was prepared using the potato dextrose agar plate method described in Gilbert and Woods (2006). Natural rainfall and irrigation rehydrated the corn inoculum and initiated fungal growth and sporulation. Metconazole fungicide was applied at the recommended $50 \%$ anthesis crop growth stage (BBCH 65; Lancashire et al. 1991) at 1,000 $\mathrm{ml} / \mathrm{ha}$ with a tractor-mounted sprayer (manufacturer) at a carrier volume of 110 liters/ha.

Disease- and yield-related variables. Disease assessment was conducted at 21 to 23 days after the $50 \%$ anthesis crop stage $\mathrm{BBCH}$ 65 . Disease incidence was measured by counting infected spikes over a total of 50 spikes collected from five random spots in each plot. Disease incidence was expressed in percentages from 0 (no spikes infected) to $100 \%$ (all samples infected). For disease severity, the proportion of each of the infected spikes was assessed with the aid of a standard area diagram (Stack and McMullen 1998). The FHB index was calculated for each plot using the following formula: FHB index $=($ percent disease incidence $\times$ percent disease severity $) / 100$. A random subsample of approximately $10 \mathrm{~g}$ of seed from handharvested samples was ground to meal using $2 \mathrm{~g}$ for DON assessment. The analysis of DON was carried out using Thermo Fisher's Gallery Analyzer based on the enzyme linked immunosorbent assay described by Sinha et al. (1995), with two technical replications for each sample from a plot, and the values were averaged in parts per million (ppm). For yield, subsamples were taken from combineharvested grain and cleaned to remove chaff before test weight (TW; in kilograms per hectoliter) and thousand-kernel weight (TKW; in grams) were taken. TW was measured using a $600-\mathrm{ml}$ chondrometer and TKW was determined by weighing 250 random seeds multiplied by 4 . To standardize the yield traits in each plot, grain yield, TW, and TKW data were adjusted to a $14.5 \%$ moisture basis. The grain protein (GP) concentration (in percentages) was measured using the LECO FP-528 analyzer according to American Association of Cereal Chemists Method 46-30. The GP concentration was also adjusted to a $14.5 \%$ moisture basis.

Statistical analyses. Data were analyzed separately for all siteyears using the MIXED procedure in Statistical Analysis Software (SAS) version 9.4 (SAS Institute Inc., Cary, NC). Error variances of the data from all site-years, for all class variables, were tested for normality using the Shapiro-Wilk test and homogeneity of variance using the Levene's test. Heterogeneous variances were modeled using the 'repeated/group=effect' statement (Littell et al. 2006). Analysis of variance was conducted to partition variance among treatments and to investigate the effect of resistance genes on FHB phenotypic traits as well as agronomic traits and GP content. The resistance genes and fungicide treatment were considered fixed factors, and all other factors were considered random. The interaction of random factors with fixed factors was also considered random. Mean comparisons were performed using Fisher's protected least significant difference procedure to protect against Type II error. All siteyears were analyzed separately or combined in a single model (experiments/site-years were considered random) and the effects were deemed significant at $P=0.05$. FE for FHB incidence, severity, index, DON, and grain yield was expressed as the percent reduction or control (Paul et al. 2008). To calculate FE, means of all four NILs (MR) carrying specific FHB resistance genes were combined and compared with CDC Go (MS) using raw phenotypic data. The raw data for all site-years were combined and used to generate least squares means for calculation of FE. Pearson's correlation coefficients for each pair of the response variables were calculated using the CORR procedure in SAS. Except for the correlation analyses, all other analyses were performed by excluding Carberry, as the purpose of the study was to examine the effects and interactions under a similar genetic background; Carberry was not expected to behave similarly in terms of agronomic and yield/quality traits.

Table 3. Analysis of variance ( $F$-values and corresponding $P$-values) for the experiments conducted in four site-years in Saskatchewan, Canada, to study the interaction of Fusarium head blight (FHB) resistance genes with the metconazole (Caramba) fungicide applied at $50 \%$ anthesis ${ }^{\mathrm{V}}$

\begin{tabular}{|c|c|c|c|c|c|c|c|c|}
\hline $\begin{array}{l}\text { Source of } \\
\text { variation }\end{array}$ & Incidence $(\%)^{\mathrm{w}}$ & Severity $(\%)^{x}$ & Index $(\%)^{y}$ & DON (ppm) & TW (kg/hl) & TKW (g) & Yield (kg/ha) & GP (\%) \\
\hline \multicolumn{9}{|l|}{ Saskatoon } \\
\hline G & 7.19 (0.0003) & $13.73(<\mathbf{0 . 0 0 0 1})$ & $40.45(<\mathbf{0 . 0 0 0 1})$ & $6.35(\mathbf{0 . 0 0 1 0})$ & $1.48(0.2140)$ & $2.10(0.1058)$ & $3.91(\mathbf{0 . 0 1 2 5})$ & $1.30(0.2932)$ \\
\hline $\mathrm{F}$ & $33.83(<\mathbf{0 . 0 0 0 1})$ & $0.14(0.7130)$ & $10.66(\mathbf{0 . 0 0 5 5})$ & 6.95 (0.0148) & 88.17 (<0.0001) & $71.23(<\mathbf{0 . 0 0 0 1})$ & $52.24(<\mathbf{0 . 0 0 0 1})$ & $2.21(0.1480)$ \\
\hline $\mathrm{G}^{*} \mathrm{~F}$ & $1.31(0.2882)$ & $0.51(0.7258)$ & $1.01(0.4455)$ & $1.73(0.1733)$ & $1.03(0.3843)$ & $0.41(0.7934)$ & $1.16(0.3482)$ & $1.08(0.3852)$ \\
\hline \multicolumn{9}{|c|}{ Outlook 2016} \\
\hline $\mathrm{G}$ & $14.12(<\mathbf{0 . 0 0 0 1})$ & 8.55 (0.0001) & $13.13(\mathbf{0 . 0 0 2 4})$ & $4.40(\mathbf{0 . 0 0 7 5})$ & 6.18 (0.0011) & $2.04(0.1140)$ & $1.11(0.3703)$ & $1.25(0.3114)$ \\
\hline $\mathrm{F}$ & $27.60(<\mathbf{0 . 0 0 0 1})$ & 15.69 (0.0005) & $29.94(\mathbf{0 . 0 0 0 3})$ & $8.54(\mathbf{0 . 0 4 2 8})$ & $64.50(<\mathbf{0 . 0 0 0 1})$ & $15.35(\mathbf{0 . 0 0 0 5})$ & 14.59 (0.0007) & $2.91(0.0983)$ \\
\hline $\mathrm{G}^{*} \mathrm{~F}$ & $2.50(0.0660)$ & 3.17 (0.0292) & $3.04(0.0961)$ & $0.38(0.8179)$ & $1.01(0.4182)$ & $0.96(0.4417)$ & $1.26(0.3082)$ & $0.17(0.9511)$ \\
\hline \multicolumn{9}{|c|}{ Outlook 2017} \\
\hline G & $4.62(\mathbf{0 . 0 0 9 8})$ & $13.05(<\mathbf{0 . 0 0 0 1})$ & $14.32(<\mathbf{0 . 0 0 0 1})$ & $3.41(0.0525)$ & $3.50(\mathbf{0 . 0 2 0 0})$ & $0.99(0.4258)$ & $1.32(0.2866)$ & $13.56(<\mathbf{0 . 0 0 0 1})$ \\
\hline $\mathrm{F}$ & $13.21(\mathbf{0 . 0 0 1 9 )}$ & 7.77 (0.0096) & 15.44 (0.0005) & $3.25(0.1017)$ & $3.32(0.0795)$ & $0.10(0.7524)$ & $0.16(0.6880)$ & $0.32(0.5775)$ \\
\hline $\mathrm{G}^{*} \mathrm{~F}$ & $1.37(0.5877)$ & $1.65(0.1901)$ & $2.51(0.0654)$ & $6.90(\mathbf{0 . 0 0 6 2})$ & $6.31(\mathbf{0 . 0 0 1 0})$ & $1.39(0.2614)$ & $1.51(0.2264)$ & $5.98(\mathbf{0 . 0 0 1 4 )}$ \\
\hline \multicolumn{9}{|c|}{ Melfort 2017} \\
\hline G & $12.39(<\mathbf{0 . 0 0 0 1})$ & $10.52(\mathbf{0 . 0 0 0 9 )}$ & $10.88(<\mathbf{0 . 0 0 0 1})$ & $1.49(0.2453)$ & $一^{\mathrm{z}}$ & $3.16(\mathbf{0 . 0 2 7 8})$ & $0.24(0.9135)$ & $5.78(\mathbf{0 . 0 2 3 4})$ \\
\hline $\mathrm{F}$ & 7.63 (0.0102) & $9.47(\mathbf{0 . 0 0 5 9})$ & 7.98 (0.0088) & $0.24(0.6312)$ & - & $0.58(0.4541)$ & $0.49(0.4893)$ & $0.04(0.8421)$ \\
\hline $\mathrm{G}^{*} \mathrm{~F}$ & $0.76(0.5627)$ & $1.52(0.2628)$ & $0.50(0.7340)$ & $0.40(0.8087)$ & - & $0.80(0.5344)$ & $0.53(0.7140)$ & $0.88(0.5218)$ \\
\hline \multicolumn{9}{|l|}{$\begin{array}{l}\text { Combined } \\
\text { site-years }\end{array}$} \\
\hline G & $15.71(<\mathbf{0 . 0 0 0 1})$ & $24.63(<\mathbf{0 . 0 0 0 1})$ & $23.34(<\mathbf{0 . 0 0 0 1})$ & $9.08(<\mathbf{0 . 0 0 0 1})$ & $2.38(0.0560)$ & 2.49 (0.0456) & $0.89(0.4699)$ & $4.28(\mathbf{0 . 0 0 2 7})$ \\
\hline F & $80.02(<\mathbf{0 . 0 0 0 1})$ & $14.71(\mathbf{0 . 0 0 0 2})$ & $67.24(<\mathbf{0 . 0 0 0 1})$ & $8.47(\mathbf{0 . 0 0 4 4 )}$ & $73.27(<\mathbf{0 . 0 0 0 1})$ & $18.97(<\mathbf{0 . 0 0 0 1})$ & $17.22(<\mathbf{0 . 0 0 0 1})$ & $3.48(0.0642)$ \\
\hline $\mathrm{G}^{*} \mathrm{~F}$ & $1.01(0.4037)$ & $0.38(0.8196)$ & $2.07(0.0945)$ & $1.18(0.3252)$ & $0.82(0.5148)$ & $0.99(0.4127)$ & $0.45(0.7747)$ & $0.060(0.6665)$ \\
\hline $\begin{array}{l}\text { V Variance } \\
\text { incidence } \\
\text { presented } \\
\text { w Percentas } \\
\text { x Percentas } \\
\text { y FHB ind }\end{array}$ & $\begin{array}{l}\text { nponents are show } \\
\text { verity, index, deox } \\
\text { Fisher's statistics } \\
\text { f spikes infected b } \\
\text { f infected florets o } \\
\text { (percent disease }\end{array}$ & $\begin{array}{l}\text { vn along with the } \\
\text { xynivalenol (DON } \\
\text { and the correspond } \\
\text { y FHB. } \\
\text { on each spike. } \\
\text { incidence } \times \text { percen }\end{array}$ & $\begin{array}{l}\text { statistical significa } \\
\text { ) accumulation, te } \\
\text { ding probability is }\end{array}$ & $\begin{array}{l}\text { nce of genotype } \\
\text { st weight (TW), } \\
\text { given in parenthe }\end{array}$ & $\begin{array}{l}\text { (G), fungicide }(\mathrm{F}) \text {, } \\
\text { thousand-kernel } \mathrm{w} \\
\text { eses. Significant } P\end{array}$ & $\begin{array}{l}\text { and their interacti } \\
\text { eight (TKW), yiel } \\
\text {-values are bolded. }\end{array}$ & $\begin{array}{l}\text { on }\left(G^{*} F\right) \text { in each } \\
d \text {, and grain prote }\end{array}$ & $\begin{array}{l}\text { site-year on FHB } \\
\text { in (GP). Data are }\end{array}$ \\
\hline
\end{tabular}




\section{Results}

Genomic composition of NILs. The NILs were backcross three (*4) derived lines from the resistance donor parent 04GC0139 and theoretically should possess $3 \%$ of their alleles from the donor parent. Genotyping with the wheat $90 \mathrm{~K}$ assay allowed us to thoroughly investigate allelic composition and the proportion of alleles derived from each parent. The proportion of the genome in the NILs derived from the donor and the recurrent parents is presented in Table 2. The four NILs selected for further study carried 0.6 to $0.8 \%$ of the alleles of the resistant donor and approximately $99.0 \%$ of the alleles of the recurrent parent. Line NIL-21 did not appear to carry Fhb1, as it retained only $0.03 \%$ of the alleles on chromosome $3 \mathrm{~B}$ from the donor parent, whereas other NILs carrying Fhbl would carry 0.9 to $1.3 \%$ of the alleles from the donor parent (Table 2). Although NIL-2 carried $F h b 1$ and it showed a smaller proportion of $3 \mathrm{~B}$ alleles from the recurrent parent, the line possessed a PFT gene, the candidate for Fhbl. Except for NIL-21, which carried Fhb2, the NILs did not carry $>0.1 \%$ alleles on chromosome 6B from the donor parent. Similarly, the lower proportion of alleles on chromosome $5 \mathrm{~A}$ from the donor parent suggests that NIL-38 does not carry Fhb5. Genotyping with molecular markers that flanked the gene interval further confirmed these results.

Table 4. Least squares means (sprayed plus unsprayed) of Fusarium head blight (FHB) incidence, severity, index, deoxynivalenol accumulation (DON), test weight (TW), thousand-kernel weight (TKW), yield, and grain protein for the near-isogenic lines (NILs) carrying FHB resistance genes in four site-year field trials ${ }^{\mathrm{v}}$

\begin{tabular}{|c|c|c|c|c|c|c|c|c|}
\hline Genotype/NIL (gene) & Incidence $(\%)^{\mathrm{w}}$ & Severity $(\%)^{x}$ & Index $(\%)^{y}$ & DON (ppm) & TW (kg/hl) & TKW (g) & Yield (kg/ha) & Protein $(\%)$ \\
\hline \multicolumn{9}{|l|}{ Saskatoon 2016} \\
\hline $\begin{array}{l}\text { Carberry } \\
\text { (moderately } \\
\text { resistant) }\end{array}$ & 22.3 & 19.0 & 4.2 & 2.6 & 80.4 & 34.4 & 3,286 & 16.1 \\
\hline $\begin{array}{l}\text { CDC Go } \\
\text { (moderately } \\
\text { susceptible NIL } \\
\text { parent) }\end{array}$ & $38.8 \mathrm{a}$ & $46.6 \mathrm{a}$ & $18.0 \mathrm{a}$ & $5.6 \mathrm{a}$ & $77.4 \mathrm{a}$ & $37.7 \mathrm{a}$ & $3,040 \mathrm{bc}$ & $15.8 \mathrm{a}$ \\
\hline NIL-38 (Fhb1) & $31.1 \mathrm{~b}$ & $31.3 \mathrm{~b}$ & $9.8 \mathrm{~b}$ & $4.2 \mathrm{~b}$ & $77.4 \mathrm{a}$ & $37.1 \mathrm{a}$ & $3,103 a b c$ & $15.6 \mathrm{a}$ \\
\hline NIL-21 (Fhb5) & $31.4 \mathrm{~b}$ & $31.3 \mathrm{~b}$ & $9.7 \mathrm{~b}$ & $2.6 \mathrm{c}$ & $77.1 \mathrm{a}$ & $36.0 \mathrm{a}$ & $2,886 \mathrm{c}$ & $15.4 \mathrm{a}$ \\
\hline $\begin{array}{l}\text { NIL-2 }(F h b 1+ \\
\quad F h b 5)\end{array}$ & $28.9 \mathrm{~b}$ & $29.9 \mathrm{~b}$ & $8.5 \mathrm{~b}$ & $3.3 \mathrm{bc}$ & $77.8 \mathrm{a}$ & $36.4 \mathrm{a}$ & $3,261 \mathrm{ab}$ & $15.5 \mathrm{a}$ \\
\hline $\begin{array}{r}\text { NIL-28 }(F h b 1+ \\
F h b 2+F h b 5)\end{array}$ & $27.3 \mathrm{~b}$ & $24.1 \mathrm{c}$ & $6.6 \mathrm{c}$ & $2.1 \mathrm{c}$ & $77.5 \mathrm{a}$ & $36.3 \mathrm{a}$ & $3,344 \mathrm{a}$ & $15.3 \mathrm{a}$ \\
\hline \multicolumn{9}{|l|}{ Outlook 2016} \\
\hline Carberry & 34.3 & 9.8 & 4.5 & 2.2 & 79.5 & 36.1 & 2,882 & 17.2 \\
\hline CDC Go & $51.3 \mathrm{a}$ & $17.3 \mathrm{a}$ & $9.1 \mathrm{a}$ & $4.6 \mathrm{a}$ & $76.3 \mathrm{~b}$ & $39.5 \mathrm{a}$ & $3,161 \mathrm{a}$ & $16.0 \mathrm{a}$ \\
\hline NIL-38 (Fhb1) & $38.1 \mathrm{bc}$ & $11.1 \mathrm{~b}$ & $4.2 \mathrm{~b}$ & $3.6 \mathrm{ab}$ & $76.3 \mathrm{~b}$ & $39.0 \mathrm{a}$ & $3,610 \mathrm{a}$ & $15.8 \mathrm{a}$ \\
\hline NIL-21 (Fhb5) & $40.0 \mathrm{~b}$ & $13.3 \mathrm{~b}$ & $5.6 \mathrm{~b}$ & $2.4 \mathrm{bc}$ & $76.9 \mathrm{a}$ & $39.0 \mathrm{a}$ & $3,224 \mathrm{a}$ & $15.3 \mathrm{a}$ \\
\hline $\begin{array}{l}\text { NIL-2 }(F h b 1+ \\
\quad F h b 5)\end{array}$ & $36.3 \mathrm{bc}$ & $13.1 \mathrm{~b}$ & $4.7 \mathrm{~b}$ & $2.1 \mathrm{c}$ & $77.0 \mathrm{a}$ & $40.6 \mathrm{a}$ & 2,978 a & $16.2 \mathrm{a}$ \\
\hline $\begin{array}{r}\text { NIL-28 }(F h b 1+ \\
F h b 2+F h b 5)\end{array}$ & $31.3 \mathrm{c}$ & $10.5 \mathrm{c}$ & $3.3 \mathrm{c}$ & $2.4 \mathrm{bc}$ & $76.7 \mathrm{ab}$ & 39.7 a & 3,206 a & $16.0 \mathrm{a}$ \\
\hline \multicolumn{9}{|l|}{ Outlook 2017} \\
\hline Carberry & 15.0 & 8.0 & 1.2 & $0.68 \mathrm{a}$ & 79.0 & $38.3 \mathrm{a}$ & $5,570 \mathrm{a}$ & 15.4 \\
\hline CDC Go & $39.4 \mathrm{a}$ & $19.0 \mathrm{a}$ & $7.8 \mathrm{a}$ & $0.66 \mathrm{a}$ & $77.3 \mathrm{a}$ & $41.8 \mathrm{a}$ & $5,640 \mathrm{a}$ & $16.0 \mathrm{a}$ \\
\hline NIL-38 (Fhb1) & $28.1 \mathrm{~b}$ & $14.4 \mathrm{~b}$ & $4.1 \mathrm{~b}$ & $0.93 \mathrm{a}$ & $76.6 \mathrm{~b}$ & $38.8 \mathrm{a}$ & 5,889 a & $16.0 \mathrm{a}$ \\
\hline NIL-21 (Fhb5) & $28.1 \mathrm{~b}$ & $10.4 \mathrm{~cd}$ & $2.9 \mathrm{bc}$ & $0.24 \mathrm{a}$ & $76.7 \mathrm{~b}$ & $39.7 \mathrm{a}$ & $5,760 \mathrm{a}$ & $15.5 \mathrm{~b}$ \\
\hline $\begin{array}{l}\text { NIL-2 }(F h b 1+ \\
\quad F h b 5)\end{array}$ & $24.4 \mathrm{~b}$ & $12.4 \mathrm{bc}$ & $3.1 \mathrm{bc}$ & $0.50 \mathrm{a}$ & $77.1 \mathrm{a}$ & $41.3 \mathrm{a}$ & 6,162 a & $16.0 \mathrm{a}$ \\
\hline $\begin{array}{r}\text { NIL-28 }(F h b 1+ \\
F h b 2+F h b 5)\end{array}$ & $23.8 \mathrm{~b}$ & $9.1 \mathrm{~cd}$ & $2.2 \mathrm{c}$ & $0.87 \mathrm{a}$ & $76.9 \mathrm{ab}$ & $40.5 \mathrm{a}$ & 5,877 a & $15.9 \mathrm{a}$ \\
\hline \multicolumn{9}{|l|}{ Melfort 2017} \\
\hline Carberry & 6.0 & 9.5 & 0.6 & 0.32 & $-^{\mathrm{z}}$ & 38.8 & 4,368 & 15.1 \\
\hline CDC Go & $21.3 \mathrm{a}$ & $22.7 \mathrm{a}$ & $5.0 \mathrm{a}$ & $0.58 \mathrm{a}$ & - & $41.7 \mathrm{a}$ & $4,545 \mathrm{a}$ & $14.3 \mathrm{~b}$ \\
\hline NIL-38 (Fhb1) & $13.1 \mathrm{~b}$ & $17.3 \mathrm{~b}$ & $2.3 \mathrm{~b}$ & $0.95 \mathrm{a}$ & - & $41.9 \mathrm{a}$ & $4,447 \mathrm{a}$ & $15.1 \mathrm{a}$ \\
\hline NIL-21 (Fhb5) & $11.9 \mathrm{bc}$ & $18.0 \mathrm{~b}$ & $2.3 \mathrm{~b}$ & $0.35 \mathrm{a}$ & - & $40.0 \mathrm{~b}$ & 4,370 a & $13.9 \mathrm{c}$ \\
\hline $\begin{array}{l}\text { NIL-2 }(F h b 1+ \\
\quad F h b 5)\end{array}$ & $11.1 \mathrm{bc}$ & $15.5 \mathrm{bc}$ & $1.8 \mathrm{~b}$ & $0.43 \mathrm{a}$ & - & $41.7 \mathrm{a}$ & 4,380 a & $14.7 \mathrm{ab}$ \\
\hline $\begin{array}{r}\text { NIL-28 }(F h b 1+ \\
F h b 2+F h b 5)\end{array}$ & $9.7 \mathrm{c}$ & $12.0 \mathrm{c}$ & $1.2 \mathrm{~b}$ & $0.37 \mathrm{a}$ & - & $41.3 \mathrm{a}$ & 4,443 a & $14.2 \mathrm{~b}$ \\
\hline \multicolumn{9}{|l|}{ Combined site-years } \\
\hline \multicolumn{9}{|l|}{ Carberry } \\
\hline CDC Go & $37.7 \mathrm{a}$ & $23.8 \mathrm{a}$ & $9.1 \mathrm{a}$ & $2.9 \mathrm{a}$ & $77.0 \mathrm{a}$ & $40.2 \mathrm{a}$ & 4,769 a & $15.5 \mathrm{a}$ \\
\hline NIL-38 (Fhb1) & $27.7 \mathrm{~b}$ & $17.2 \mathrm{~b}$ & $5.0 \mathrm{~b}$ & $2.4 \mathrm{a}$ & $76.8 \mathrm{a}$ & $39.2 \mathrm{ab}$ & $4,938 \mathrm{a}$ & $15.7 \mathrm{a}$ \\
\hline NIL-21 (Fhb5) & $27.4 \mathrm{bc}$ & $16.2 \mathrm{~b}$ & $4.6 \mathrm{bc}$ & $1.3 \mathrm{~b}$ & $76.9 \mathrm{a}$ & $38.7 \mathrm{~b}$ & $4,724 \mathrm{a}$ & $15.2 \mathrm{~b}$ \\
\hline $\begin{array}{l}\text { NIL-2 }(F h b 1+ \\
\quad F h b 5)\end{array}$ & $22.9 \mathrm{~d}$ & $16.5 \mathrm{~b}$ & $3.7 \mathrm{~cd}$ & $1.5 \mathrm{~b}$ & $77.3 \mathrm{a}$ & $40.0 \mathrm{a}$ & $2,861 \mathrm{a}$ & $15.6 \mathrm{a}$ \\
\hline $\begin{array}{r}\text { NIL-28 }(F h b 1+ \\
F h b 2+F h b 5)\end{array}$ & $23.3 \mathrm{~cd}$ & $11.7 \mathrm{c}$ & $2.8 \mathrm{~d}$ & $1.2 \mathrm{~b}$ & $77.1 \mathrm{a}$ & $39.4 \mathrm{ab}$ & 4,893 a & $15.4 \mathrm{ab}$ \\
\hline
\end{tabular}

$\mathrm{v}_{\mathrm{VW}} \mathrm{TW}$ TKW, yield, and grain protein estimates are based on constant moisture content. Means comparison was performed without inclusion of Carberry. Means followed by the same letter within columns are not significantly different (least significant difference, $P<0.05$ ). Carberry was not included in the mean comparisons because it was not expected to behave similarly to CDC Go and NILs because of a different genetic background.

w Percentage of spikes infected by FHB.

$x$ Percentage of infected florets on each spike.

y $\mathrm{FHB}$ index $=($ percent disease incidence $\times$ percent disease severity $) / 100$.

z Dashes indicate not measured. 
Single and interaction factor effects. The random effects of replication (plot), interactions of replication by fungicide treatment, and genotype (NILs) were not significant (data not shown). In general, $F$-value estimates were greater for fungicide than genotype factor in 2016 and the reverse was observed in 2017. For FHB-related variables (incidence, severity, index, and DON accumulation), $F$-values for genotype and fungicide factors were significant for all variables but DON accumulation in Outlook 2017 and Melfort 2017 and severity in Saskatoon 2016 (Table 3). Among agronomic traits, fungicide improved each of the agronomic traits only in 2016 trials and genotype differences for yield in Saskatoon 2016, TW in Outlook 2016 and Outlook 2017, and TKW in Melfort 2017 trials. For GP, $F$-values were significant for genotype only in 2017 . The genotype-by-fungicide interaction was significant for the following variables: severity in Outlook 2016 and DON, TW, and GP in Outlook 2017. Variance estimates for interactions were higher (greater $F$-values) for Outlook 2017 than other site-years, whereas they were marginal for disease severity, especially with Outlook 2016. For combined site-years analyses, $F$-values were significant for genotypes for all traits except TW and yield and for fungicide treatment for all traits except GP. Interaction of genotype by treatment was not significant for any of the evaluated traits in the combined analyses.

All NILs performed better than their recurrent parent CDC Go for all disease symptom parameters. In terms of FHB incidence, none of the NILs differed from each other in Saskatoon 2016 or Outlook 2017, whereas NIL-28 performed better than NIL-21 in Outlook 2016 and NIL-38 in Melfort 2017, respectively. In 2016, the FHB severity of NIL-28 was lower than that of the other three NILs. In Outlook 2017, FHB severity of NIL-2, NIL-21, and NIL-28 was comparable and better than NIL-38; in Melfort 2017, NIL-28 was less severely affected compared with NIL-21 and NIL-38. The FHB index of NIL-28 was lower than other NILs, although NIL-21 and NIL-2 were comparable in Outlook 2017. In Saskatoon 2016, NIL-38 and NIL-2 were comparable for DON accumulation, whereas NIL-21 and NIL-28 had significantly lower DON. In Outlook 2016, DON accumulation of NIL-38 was not different from CDC Go, while all other NILs were similar to each other. In 2016, when genotypes differed for DON accumulation, irrespective of resistance level or fungicide treatment, all genotypes had more than $1 \mathrm{ppm}$ DON (data not shown). DON measurements in 2017 were lower than in 2016, which could be attributed to relatively lower incidence (Table 4; data not shown). Wherever genotype-by-fungicide interactions were significant, this was generally attributable to the superior performance (lower disease, higher yield) of NIL-38 relative to the unsprayed control.

The NILs did not differ for agronomic traits in most of the environments (Table 4). For TW, NIL-2 and NIL-28 were similar in Outlook 2016 and Outlook 2017, the only two site-years where the NILs differed for the trait. The TW of NIL-38 was consistently lower than NIL-2 in both site-years. For TKW, NILs differed only in Melfort 2017; NIL-21 had lower TKW than the other three NILs or the recurrent parent CDC Go. Similarly, for grain yield, the NILs differed only in Saskatoon 2016. The yield of NIL-28 was higher than CDC Go and NIL-21. Grain yield was lowest for NIL-21, although it differed significantly only from NIL-2 and NIL-28. Differences among NILs for GP were observed in 2017, where NIL-21 had the lowest GP content in both site-years. In Outlook 2017, GP of CDC Go was comparable to that of the NILs, except for NIL-21, which showed slightly lower GP relative to others. In Melfort 2017, NIL-38 had the highest GP content than that of CDC Go, NIL-21, and NIL-28. In addition to GP, significant differences were observed for fungicide treatment in at least two of the four site-years (Table 5). Wherever significant, lines receiving fungicide treatment showed lower disease measurements and higher TW, TKW, and yield. For combined site-years analyses, results were concordant with most of the individual siteyear analyses.

Correlation analysis and FE. Strong positive associations $(R>$ $0.60, P=0.001)$ were observed between pairwise combinations of FHB incidence, severity, and index, whereas the disease estimates showed positive but only moderate correlation with DON $(R=$ 0.35 to $0.59, P=0.05$ ) (Table 6). FHB incidence, severity, index, and DON accumulation were negatively correlated with the agronomic traits TW, TKW, and grain yield, whereas the agronomic traits were sometimes positively correlated among themselves but in other instances they were not significant (e.g., for Outlook 2016, yield with TW and TKW, and in Outlook 2017, yield with TW). FE was higher on CDC Go (MS) than that on the MR NILs for all of the parameters measured except FHB incidence (Fig. 1). Among the genotypes, FE was generally not significant, irrespective of the FHB incidence, severity and index, DON, or grain yield.

\section{Discussion}

To our knowledge, this is the first study on the effect of individual and combinations of Sumai 3 genes in a near-isogenic background.

Table 5. Least squares means of Fusarium head blight (FHB) incidence, severity, index, deoxynivalenol accumulation (DON), test weight (TW), thousand-kernel weight (TKW), yield, and grain protein for fungicide treatment (Caramba, metconazole, Group 3; BASF Canada) at four site-years in Saskatchewan ${ }^{\mathrm{v}}$

\begin{tabular}{|c|c|c|c|c|c|c|c|c|}
\hline Fungicide treatment & Incidence $(\%)^{\mathrm{w}}$ & Severity $(\%)^{x}$ & Index $(\%)^{y}$ & DON (ppm) & TW (kg/hl) & TKW (g) & Yield (kg/ha) & Protein $(\%)$ \\
\hline \multicolumn{9}{|l|}{ Saskatoon 2016} \\
\hline Sprayed & $27.2 \mathrm{~b}$ & $32.2 \mathrm{a}$ & $9.2 \mathrm{~b}$ & $2.9 \mathrm{~b}$ & $78.4 \mathrm{a}$ & $38.5 \mathrm{a}$ & $3,423 \mathrm{a}$ & $15.6 \mathrm{a}$ \\
\hline Unsprayed & $35.8 \mathrm{a}$ & $33.0 \mathrm{a}$ & $11.9 \mathrm{a}$ & $4.2 \mathrm{a}$ & $76.5 \mathrm{~b}$ & $34.8 \mathrm{~b}$ & $2,831 \mathrm{~b}$ & $15.4 \mathrm{a}$ \\
\hline \multicolumn{9}{|l|}{ Outlook 2016} \\
\hline Sprayed & $34.8 \mathrm{~b}$ & $11.5 \mathrm{~b}$ & $4.1 \mathrm{~b}$ & $2.2 \mathrm{~b}$ & $77.5 \mathrm{a}$ & $40.4 \mathrm{a}$ & $3,610 \mathrm{a}$ & $16.1 \mathrm{a}$ \\
\hline Unsprayed & $44.0 \mathrm{a}$ & $14.7 \mathrm{a}$ & $6.7 \mathrm{a}$ & $3.5 \mathrm{a}$ & $76.7 \mathrm{~b}$ & $38.7 \mathrm{~b}$ & $2,862 \mathrm{~b}$ & $15.6 \mathrm{a}$ \\
\hline \multicolumn{9}{|l|}{ Outlook 2017} \\
\hline Sprayed & $24.0 \mathrm{a}$ & $11.7 \mathrm{~b}$ & $3.0 \mathrm{a}$ & $0.52 \mathrm{a}$ & $77.4 \mathrm{a}$ & $40.6 \mathrm{a}$ & $5,896 \mathrm{a}$ & $15.9 \mathrm{a}$ \\
\hline Unsprayed & $33.5 \mathrm{~b}$ & $14.4 \mathrm{a}$ & $5.1 \mathrm{a}$ & $0.76 \mathrm{a}$ & $77.0 \mathrm{~b}$ & $40.2 \mathrm{a}$ & $5,834 \mathrm{a}$ & $15.9 \mathrm{a}$ \\
\hline \multicolumn{9}{|l|}{ Melfort 2017} \\
\hline Sprayed & $11.6 \mathrm{~b}$ & $14.5 \mathrm{~b}$ & $1.4 \mathrm{~b}$ & $0.47 \mathrm{a}$ & $一^{\mathrm{z}}$ & $41.5 \mathrm{a}$ & $4,480 \mathrm{a}$ & $14.5 \mathrm{a}$ \\
\hline Unsprayed & $14.7 \mathrm{a}$ & $18.6 \mathrm{a}$ & $2.8 \mathrm{a}$ & $0.56 \mathrm{a}$ & - & $41.1 \mathrm{a}$ & $4,393 \mathrm{a}$ & $14.4 \mathrm{a}$ \\
\hline \multicolumn{9}{|l|}{ Combined site-years } \\
\hline Sprayed & $21.8 \mathrm{~b}$ & $15.7 \mathrm{~b}$ & $3.5 \mathrm{~b}$ & $1.5 \mathrm{~b}$ & $77.5 \mathrm{a}$ & $40.2 \mathrm{a}$ & $4,352 \mathrm{a}$ & $15.6 \mathrm{a}$ \\
\hline Unsprayed & $33.8 \mathrm{a}$ & $18.5 \mathrm{a}$ & $6.6 \mathrm{a}$ & $2.2 \mathrm{a}$ & $76.5 \mathrm{~b}$ & $38.7 \mathrm{~b}$ & $4,004 \mathrm{~b}$ & $15.4 \mathrm{a}$ \\
\hline
\end{tabular}

$\mathrm{v}$ TW, TKW, yield, and grain protein estimates were based on moisture content of $14.5 \%$. Means comparison was performed after excluding Carberry. Means followed by the same letter within columns are not based on Fisher's least significant differences at $P<0.05$.

w Percentage of spikes infected from total spikes.

$x$ Percentage of the florets of each spike infected with FHB.

y $\mathrm{FHB}$ index $=($ percent disease incidence $\times$ percent disease severity $) / 100$.

z Not measured. 
Carberry was not used for the mean comparisons because of the difference in genetic background and it possibly carries minor QTLs for FHB resistance in addition to $F h b l$ and $F h b 5$. Although CDC Go is an MS cultivar and also carries three very minor FHB resistance loci (on chromosomes 1DL, 2AL, and 2DL), these three loci are equally distributed in the NILs (Brar et al. 2019a); thus, their presence is not expected to influence the overall results and conclusions of this study. We used only one triazole fungicide in our study to avoid potentially more complex genotype-by-fungicide interactions as reported previously (Amarasinghe et al. 2013; Mesterházy et al. 2003). Metconazole was among the best fungicide active ingredients to reduce FHB and DON, according to a meta-analysis comprising $>100$ uniform fungicide trials conducted in the United States (Paul et al. 2008). It is also on the recommended list of fungicides for suppressing FHB and DON in western Canada (Saskatchewan Seed Growers Association 2018). We utilized NILs carrying $<1.0 \%$ of the alleles from the resistant donor parent to estimate gene-by-fungicide interactions with minimized interference caused by a different genetic background.

Host resistance and fungicide treatment both elicited responses to yield and disease measurements and most agronomic/end-use quality traits (TW, TKW, and GP) in this study. The positive correlations among FHB index and DON and negative correlations of FHB index with yield traits are consistent with previous studies (Gilbert and Haber 2013; McMullen et al. 2012). Nonsignificant genotypeby-fungicide interactions for disease parameters suggests an additive response of Sumai 3-derived genes to metconazole (Table 3). We observed an interaction of $F h b l$ with the fungicide for FHB severity and
DON, respectively, in only one site-year each, which could be attributed to environmental or unknown factors. FHB affects yield and related traits by causing bleaching of infected spikes and affecting the vascular system, which result in overall lower TW and TKW. Resistant wheat genotypes are able to reduce such losses compared with susceptible ones (McMullen et al. 2012). In our study, despite carrying Fhb5, NIL-21 performed poorly (tended to have lower TW, TKW, yield, and GP) than the recurrent parent CDC Go or other NILs, which could be attributable in part to the level of disease, but these traits may also be affected by linkage drag by other alleles from the resistance donor. This was evident in separate yield trials without FHB, where NIL-21 showed poorer yield or quality traits compared with NIL-28 or CDC Go (Brar et al. 2019b).

Inconsistent findings of FE on cultivars/lines that differ for FHB resistance (more likely tolerance in old cultivars) and variable efficacy of different triazole fungicide active ingredients in previous studies have been attributed to environmental and pathogen factors (Amarasinghe et al. 2013; Blandino et al. 2012; Boyacioglu et al. 1992; D’Angelo et al. 2014; Hollingsworth et al. 2008; Mesterházy et al. 2003, 2018; Paul et al. 2008; Wegulo et al. 2011; Willyerd et al. 2012). Our study demonstrated generally greater FE for the MS cultivar CDC Go and lower efficacy on the MR NILs. This is contrary to Mesterházy et al. $(2003,2018)$ and Wegulo et al. (2011), as they reported higher FE on MR cultivars. Similar to our study, Willyerd et al. (2012) and Ye et al. (2017) also reported higher FE on MS or S cultivars. The important factor to consider among these results is the FHB pressure; in trials with moderate to high

Table 6. Pearson's correlation coefficients between Fusarium head blight (FHB) incidence, severity, index, deoxynivalenol (DON) accumulation, test weight (TW), thousand-kernel weight (TKW), and yield ${ }^{\mathrm{w}}$

\begin{tabular}{|c|c|c|c|c|c|c|c|}
\hline & Incidence $^{x}$ & Severity $^{\mathrm{y}}$ & Index $^{z}$ & DON & TW & TKW & Yield \\
\hline $\begin{array}{l}\text { Saskatoon } 2016 \\
\text { Incidence }\end{array}$ & - & & & & & & \\
\hline Severity & $0.12 \mathrm{~ns}$ & - & & & & & \\
\hline Index & $0.78^{* * *}$ & $0.67 * * *$ & - & & & & \\
\hline DON & $0.54 * *$ & $0.23 \mathrm{~ns}$ & $0.51 * *$ & - & & & \\
\hline TW & $-0.65 * * *$ & $-0.31^{*}$ & $-0.62 * * *$ & $-0.21 \mathrm{~ns}$ & - & & \\
\hline TKW & $-0.43 * *$ & $0.17 \mathrm{~ns}$ & $-0.23 \mathrm{~ns}$ & $-0.05 \mathrm{~ns}$ & $0.35^{*}$ & - & \\
\hline Yield & $-0.67 * * *$ & $-0.41^{*}$ & $-0.58 * * *$ & $-0.36^{*}$ & $0.65^{* * *}$ & $0.57 * * *$ & - \\
\hline \multicolumn{8}{|l|}{ Outlook 2016} \\
\hline Incidence & - & & & & & & \\
\hline Severity & $0.66^{* * *}$ & - & & & & & \\
\hline Index & $0.90 * * *$ & $0.86^{* * *}$ & - & & & & \\
\hline DON & $0.53 * *$ & $0.38^{*}$ & $0.53 * *$ & - & & & \\
\hline TW & $-0.46^{* *}$ & $-0.55^{* * *}$ & $-0.39 * *$ & $0.24 \mathrm{~ns}$ & - & & \\
\hline TKW & $-0.26 \mathrm{~ns}$ & $-0.30^{*}$ & $-0.32 *$ & $-0.39 * *$ & $0.33 *$ & - & \\
\hline Yield & $-0.23 \mathrm{~ns}$ & $-0.36^{*}$ & $-0.51 * *$ & $0.08 \mathrm{~ns}$ & $0.25 \mathrm{~ns}$ & $0.08 \mathrm{~ns}$ & - \\
\hline \multicolumn{8}{|l|}{ Outlook 2017} \\
\hline Incidence & - & & & & & & \\
\hline Severity & $0.56^{* *}$ & - & & & & & \\
\hline Index & $0.85 * * *$ & $0.86^{* * *}$ & - & & & & \\
\hline DON & $0.11 \mathrm{~ns}$ & $0.09 \mathrm{~ns}$ & $0.16 \mathrm{~ns}$ & - & & & \\
\hline TW & $-0.34 *$ & $-0.33^{*}$ & $-0.30^{*}$ & $-0.01 \mathrm{~ns}$ & - & & \\
\hline TKW & $0.23 \mathrm{~ns}$ & $0.16 \mathrm{~ns}$ & $0.21 \mathrm{~ns}$ & $-0.30^{*}$ & $0.10 \mathrm{~ns}$ & - & \\
\hline Yield & $-0.05 \mathrm{~ns}$ & $-0.06 \mathrm{~ns}$ & $-0.09 \mathrm{~ns}$ & $-0.16 \mathrm{~ns}$ & $0.08 \mathrm{~ns}$ & $0.32 *$ & - \\
\hline \multicolumn{8}{|l|}{ Melfort 2017} \\
\hline Incidence & - & & & & & & \\
\hline Severity & $0.74 * * *$ & - & & & & & \\
\hline Index & $0.95 * * *$ & $0.86^{* * * *}$ & - & & & & \\
\hline DON & $0.37 *$ & $0.10 \mathrm{~ns}$ & $0.25^{*}$ & - & & & \\
\hline $\mathrm{TW}$ & - & - & - & - & - & & \\
\hline TKW & $-0.08 \mathrm{~ns}$ & $-0.06 \mathrm{~ns}$ & $-0.11 \mathrm{~ns}$ & $0.13 \mathrm{~ns}$ & - & - & \\
\hline Yield & $0.03 \mathrm{~ns}$ & $-0.06 \mathrm{~ns}$ & $-0.05 \mathrm{~ns}$ & $-0.08 \mathrm{~ns}$ & - & $0.50 * *$ & - \\
\hline
\end{tabular}

${ }^{w}$ Test weight was not measured in Melfort 2017. Correlations were not significant among grain protein and any of the other traits. Correlation coefficients were significant at $* P<0.05, * * P<0.001$, and $* * * P<0.0001$, respectively. ns $=$ not significant.

${ }^{x}$ Percentage of spikes infected from total spikes.

y Percentage area of spikes infected with FHB out of infected spikes.

${ }^{\mathrm{z}} \mathrm{FHB}$ index $=($ percent disease incidence $\times$ percent disease severity $) / 100$. 


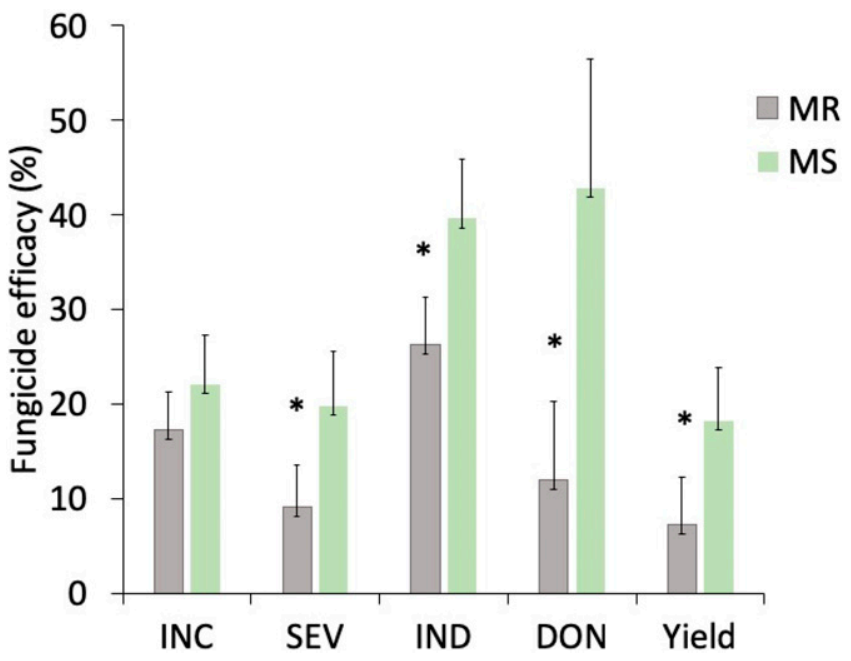

Fig. 1. Fungicide efficacy (in percentages) for Fusarium head blight incidence, severity and index, deoxynivalenol, and grain yield in moderately susceptible (CDC Go) and moderately resistant (NIL-2, NIL-21, NIL-28, and NIL-38) hard red spring wheat lines. Asterisks denote bars with a significant difference according to Fisher's least significant difference at $P=0.05$. INC = incidence, $\mathrm{SEV}=$ severity, IND = index, $\mathrm{DON}=$ deoxynivalenol, $\mathrm{MR}=$ moderately resistant, $\mathrm{MS}=$ moderately susceptible, and NIL = near-isogenic line.

disease pressure, greater FE is expected for MR genotypes because the fungicide alone would likely be insufficient on a susceptible cultivar. Under low disease pressure, however, FE can be relatively greater for MS/S genotypes because the infection level on a resistant cultivar would be too low to warrant a fungicide spray. The disease pressure reported by Mesterházy et al. $(2003,2018)$ and Wegulo et al. (2011) was much higher compared with Willyerd et al. (2012) and Ye et al. (2017). Hollingsworth et al. (2008) drew similar conclusions in their study; the level of FHB was much higher on MS/S cultivars than that on untreated MR, and thus a fixed absolute reduction in MR cultivars would translate into greater efficacy. However, this would not hold true in trials under low disease pressure, such as ours. Under the low disease pressure, the actual reduction (not a relative change) in FHB and DON was less dramatic on MR than on MS, thus resulting in higher relative FE for CDC Go, despite the fact that the ultimate disease measurements were lower on NILs. The other reason for higher FE on MR under high disease pressure may be that genetic resistance can be in several mechanisms, including type I, type II, or even type III forms over the lifetime of the plant.

The FE results in our study imply that in years with low disease pressure, such as 2017 , resistance alone is generally enough to prevent much of the yield loss caused by FHB. As a result, we did not detect yield benefits for fungicide treatments (Table 5). In years with moderate to high disease pressure (2016 in our study), however, the application of triazoles suppressed FHB and reduced the yield loss. However, it is worth mentioning that despite the improved efficacy on CDC Go relative to untreated controls, higher levels of disease were still observed on this MS cultivar relative to those on NILs (Table 4). These results indicate that application of metconazole to an MR cultivar can be beneficial under moderate to high disease pressure. DON accumulation was $>1 \mathrm{ppm}$ in both the NILs and CDC Go for the 2016 trials, which meant that even under moderate disease pressure, moderate resistance plus fungicide application may still result in a low level of DON accumulation in harvested grains. Since the FHB resistance genes are only partially effective under high disease pressure, it is not uncommon to observe little to no difference in DON accumulation or FHB index between MS and MR (Blandino et al. 2012; G. S. Brar, personal observation).

Our study demonstrated the additive nature of Sumai 3-derived FHB resistance genes with metconazole in suppressing FHB and DON accumulation in the grain. Introgression of $F h b 1$ and/or Fhb5 into hard red spring wheat should improve FHB control in Saskatchewan. Under moderate to heavy disease pressure, adding a fungicide application to MR cultivars can further enhance the effectiveness of FHB control, often increasing the grain yield. However, this strategy alone may not reduce DON accumulation to an acceptable level and thus additional options should also be considered for integrated FHB management. In western Canada, extended crop rotation may be warranted in the eastern prairies (Manitoba and eastern Saskatchewan) as a result of more severe FHB than in the western prairies, including Alberta and western Saskatchewan (Beres et al. 2018). This cultural practice should be combined with cultivar resistance and, under high disease pressure, also with fungicides. The efficacy of triazole fungicides can vary depending largely on disease pressure but also on host resistance, environmental conditions, and application methods (D'Angelo et al. 2014; McMullen et al. 2012; Paul et al. 2008). In the context of Canadian hard red spring wheat cultivation, the integration of host resistance and fungicide application in the eastern prairies is unavoidable because FHB has been a problem in that region for many years; however, wheat growers in the western prairies, particularly the province of Alberta, may not yet benefit from fungicide application if FHB is not usually severe. In fact, the adoption of FHB-resistant cultivars has increased in Manitoba more than in Alberta, which reflects the experience of wheat growers with FHB (Beres et al. 2018). Although preventing DON accumulation is very important from an international trade and market viewpoint, in the end, DON is an economic issue when present. Wheat growers should consider all possible strategies to manage FHB under moderate or higher disease pressure. To bring DON levels down to an acceptable limit, growers should not just rely on host resistance and fungicide application but should also consider cultural practices and most importantly a minimum of 4-year crop rotation, which has also been evidenced in other pathosystems in wheat in western Canada (Kutcher et al. 2018).

\section{Acknowledgments}

The authors acknowledge technical assistance from Stephanie Ginter (Agriculture and Agri-Food Canada, Melfort Research Station, Melfort, SK, Canada) and Mallory Dyck, Everett Boots, Angel Liew, Gursahib Singh, Kun Lou, and Gopal Sharma (Crop Development Centre, University of Saskatchewan, Saskatoon, SK, Canada).

\section{Literature Cited}

Amarasinghe, C. C., Tamburic-Ilincic, L., Gilbert, J., Brûlé-Babel, A., and Fernando, W. G. D. 2013. Evaluation of different fungicides for control of Fusarium head blight in wheat inoculated with $3 \mathrm{ADON}$ and 15ADON chemotypes of Fusarium graminearum in Canada. Can. J. Plant Pathol. 35:200-208.

Bai, G., Su, Z., and Cai, J. 2018. Wheat resistance to Fusarium head blight. Can. J. Plant Pathol. 40:336-346.

Beres, B. L., Brule-Babel, A. L., Ye, Z., Graf, R. J., Turkington, T. K., Harding, M. W., Kutcher, H. R., and Hooker, D. C. 2018. Exploring genotype $\times$ environment $\times$ management synergies to manage Fusarium head blight in wheat. Can. J. Plant Pathol. 40:179-188.

Bissonnette, K. M., Kolb, F. L., Ames, K. A., and Bradley, C. A. 2018. Effect of Fusarium head blight management practices on mycotoxin contamination of wheat straw. Plant Dis. 102:1141-1147.

Blandino, M., Haidukowski, M., Pascale, M., Plizzari, L., Scudellari, D., and Reyneri, A. 2012. Integrated strategies for the control of Fusarium head blight and deoxynivalenol contamination in winter wheat. Field Crops Res. 133:139-149.

Boyacioglu, D., Hettiarachchy, N. S., and Stack, R. W. 1992. Effect of three systemic fungicides on deoxynivalenol (vomitoxin) production by Fusarium graminearum in wheat. Can. J. Plant Sci. 72:93-101.

Brar, G. S., Brûlé-Babel, A. L., Ruan, Y., Henriquez, M. A., Pozniak, C. J., Kutcher, H. R., and Hucl, P. J. 2019a. Genetic factors affecting Fusarium head blight resistance improvement from introgression of exotic Sumai 3 alleles (including Fhb1, Fhb2, and Fhb5) in hard red spring wheat. BMC Plant Biol. [accepted].

Brar, G. S., Dhariwal, R., and Randhawa, H. S. 2018. Resistance evaluation of differentials and commercial wheat cultivars to stripe rust (Puccinia striiformis) infection in hot spot regions of Canada (published correction appears in Eur. J. Plant Pathol. 2018;152:269). Eur. J. Plant Pathol. 152:493-502.

Brar, G. S., Pozniak, C. J., Kutcher, H. R., and Hucl, P. J. 2019b. Evaluation of Fusarium head blight resistance genes Fhb1, Fhb2, and Fhb5 introgressed into elite Canadian hard red spring wheats: Effect on agronomic and end-use quality traits and implications for breeding. Mol. Breeding. 39:44. https:// doi.org/10.1007/s11032-019-0957-8

Buerstmayr, M., Steiner, B., Wagner, C., Schwarz, P., Brugger, K., Barabaschi, D., Volante, A., Vale, G., Cattivelli, L., and Buerstmayr, H. 2018. High-resolution 
mapping of the pericentromeric region on wheat chromosome arm 5AS harbouring the Fusarium head blight resistance QTL Qfhs.ifa-5A. Plant Biotechnol. J. 16:1046-1056.

Cholango-Martinez, L. P., Zhang, X. M., Hucl, P. J., and Kutcher, H. R. 2016. First report of Fusarium head blight, caused by Fusarium graminearum, on annual canarygrass (Phalaris canariensis) in Saskatchewan, Canada. Plant Dis. 100: 1780.

Cools, H. J., Hawkins, N. J., and Fraaije, B. A. 2013. Constraints on the evolution of azole resistance in plant pathogenic fungi. Plant Pathol. 62(Suppl 1):36-42.

Cuthbert, P. A., Somers, D. J., and Brûlé-Babel, A. 2007. Mapping of Fhb2 on chromosome 6BS: A gene controlling Fusarium head blight field resistance in bread wheat (Triticum aestivum L.). Theor. Appl. Genet. 114:429-437.

D'Angelo, D. L., Bradley, C. A., Ames, K. A., Willyerd, K. T., Madden, L. V., and Paul, P. A. 2014. Efficacy of fungicide applications during and after anthesis against Fusarium head blight and deoxynivalenol in soft red winter wheat. Plant Dis. 98:1387-1397.

DePauw, R. M., Knox, R. E., McCaig, T. N., Clarke, F. R., and Clarke, J. M. 2011. Carberry hard red spring wheat. Can. J. Plant Sci. 91:529-534

Gilbert, J., Brule-Babel, A., Guerrieri, A. T., Clear, R. M., Patrick, S., Slusarenko, K., and Wolfe, C. 2014. Ratio of 3-ADON and 15-ADON isolates of Fusarium graminearum recovered from wheat kernels in Manitoba from 2008 to 2012. Can. J. Plant Pathol. 36:54-63.

Gilbert, J., and Haber, S. 2013. Overview of some recent research developments in Fusarium head blight of wheat. Can. J. Plant Pathol. 35:149-174.

Gilbert, J., and Woods, S. M. 2006. Strategies and considerations for multilocation FHB screening nurseries. Pages 93-102 In: The Global Fusarium Initiative for International Collaboration: A Strategic Planning Workshop, CIMMYT; 14-17 March 2006; El Batan, Mexico. T. Ban, J. M. Lewis, and E. E. Phipps, eds. International Maize and Wheat Improvement Center, Mexico City, Mexico.

Hollingsworth, C. R., Motteberg, C. D., Wiersma, J. V., and Atkinson, L. M. 2008. Agronomic and economic responses of spring wheat to management of Fusarium head blight. Plant Dis. 92:1339-1348.

Kutcher, H. R., Turkington, T. K., McLaren, D. L., Irvine, R. B., and Brar, G. S. 2018. Fungicide and cultivar management of leaf spot diseases of winter wheat in western Canada. Plant Dis. 102:1828-1833.

Lancashire, P. D., Bleiholder, H., Langeluddecke, P., Stauss, R., van den Boom, T., Weber, E., and Witzenberger, A. 1991. A uniform decimal code for growth stages of crops and weeds. Ann. Appl. Biol. 119:561-601.

Littell, R. C., Milliken, G. A., Stroup, W. W., Wolfinger, R., and Schabenberger, O. 2006. SAS for Mixed Models, 2nd ed. SAS Institute Inc., Cary, NC.

Liu, S., Pumphrey, M. O., Gill, B. S., Trick, H., Zhang, J. X., Dolezel, J., Chalhoub, B., and Anderson, J. A. 2008. Towards positional cloning of $F h b 1$, a major QTL for Fusarium head blight resistance in wheat. Cereal Res. Commun. 36(Suppl 6):195-201.

McMullen, M., Bergstrom, G., de Wolf, E., Dill-Macky, R., Hershamn, D., Shaner, G., and Van Sanford, D. 2012. A unified effort to fight an enemy of wheat and barley: Fusarium head blight. Plant Dis. 96:1712-1728.

McMullen, M. P., Jones, R., and Gallenberg, D. 1997. Scab of wheat and barley-A re-emerging disease of devastating impact. Plant Dis. 81:1340-1348.

Mesterházy, A., Bartok, T., and Lamper, C. 2003. Influence of wheat cultivar, species of Fusarium, and isolate aggressiveness on the efficacy of fungicides for control of Fusarium head blight. Plant Dis. 87:1107-1115.

Mesterházy, Á., Varga, M., Tóth, B., Kotai, C., Bartók, T., Véha, A., Ács, K., Vágvölgyi, C., and Lehoczki-Krsjak, S. 2018. Reduction of deoxynivalenol (DON) contamination by improved fungicide use in wheat. Part 1. Dependence on epidemic severity and resistance level in small plot tests with artificial inoculation. Eur. J. Plant Pathol. 151:39-55.
Paul, P. A., Bradley, C. A., Madden, L. V., Dalla Lana, F., Bergstrom, G. C., DillMacky, R., Wise, K. A., Esker, P. D., McMullen, M., Grybauskas, A., Kirk, W. W., Milus, E. A., and Ruden, K. 2018. Effects of pre- and post-anthesis applications of demethylation inhibitor fungicides on Fusarium head blight and deoxynivaelnol in spring and winter wheat. Plant Dis. 102:2500-2510.

Paul, P. A., Lipps, P. E., Hershman, D. E., McMullen, M. P., Draper, M. A., and Madden, L. V. 2008. Efficacy of triazole-based fungicides for Fusarium head blight and deoxynivalenol control in wheat: A multivariate meta-analysis. Phytopathology 98:999-1011.

Rawat, N., Pumphrey, M. O., Liu, S., Zhang, X., Tiwari, V. K., Ando, K., Trick, H N., Bockus, W. W., Akhunov, E., Anderson, J. A., and Gill, B. S. 2016. Wheat Fhbl encodes a chimeric lectin with agglutinin domians and a pore-forming toxin-like domain conferring resistance to Fusarium head blight. Nat. Genet. 48:1576-1580.

Saskatchewan Seed Growers Association. 2018. Varieties of Grain Crops 2018 Saskatchewan Seed Growers Association, Saskatoon, SK, Canada.

Scala, V., Aureli, G., Cesarano, G., Incerti, G., Fanelli, C., Scala, F., Reverberi, M and Bonanomi, G. 2016. Climate, soil management, and cultivar affect Fusarium head blight incidence and deoxynivalenol accumulation in durum wheat of southern Italy. Front. Microbiol. 7:1014

Sinha, R. C., Savard, M. E., and Lau, R. 1995. Production of monoclonal antibodies for the specific detection of deoxynivalenol and 15-acetyldeoxynivalenol by ELISA. J. Agric. Food Chem. 43:1740-1744.

Stack, R. W., and McMullen, M. P. 1998. A Visual Scale to Estimate Severity of Fusarium Head Blight in Wheat. North Dakota State University Extension Service Small Grains Publications. Online Publication/PP-1095. https:// library.ndsu.edu/ir/handle/10365/9187

van der Lee, T., Zhang, H., van Diepeningen, A., and Waalwijk, C. 2015 Biogeography of Fusarium graminearum species complex and chemotypes: A review. Food Addit. Contam. Part A Chem. Anal. Control Expo. Risk Assess. 32:453-460.

Wang, S., Wong, D., Forrest, K., Allen, A., Chao, S., Huang, B., Maccaferri, M. Salvi, S., Milner, S. G., Cattivelli, L., Mastrangelo, A. M., Whan, A., Stephen, S., Barker, G., Wieseke, R., and Plieske, J., Lillemo, M., Mather, D., Appels, R., Dolferus, R., Brown-Guedira, G., Korol, A., Akhunova, A. R., Feuillet, C., Salse, J., Morgante, M., Pozniak, C., Luo, M.-C., Dvorak, J., Morell, M., Dubcovsky, J., Ganal, M., Tuberosa, R., Lawley, C., Mikoulitch, I., Cavanagh, C., Edwards, K. J., Hayden, M., and Akhunov, E.; International Wheat Genome Sequencing Consortium. 2014. Characterization of polyploid wheat genomic diversity using a high-density 90000 single nucleotide polymorphism array. Plant Biotechnol. J. 12:787-796.

Wegulo, S. N., Bockus, W. W., Hernandez Nopsa, J., De Wolf, E. D., Eskridge, K M., Peiris, K. H. S., and Dowell, F. E. 2011. Effects of integrating cultivar resistance and fungicide application on Fusarium head blight and deoxynivalenol in winter wheat. Plant Dis. 95:554-560.

Willyerd, K. T., Li, C., Madden, L. V., Bradley, C. A., Bergstron, G. C., Sweets, L. E., McMullen, M., Ransom, J. K., et al. 2012. Efficacy and stability of integrating fungicide and cultivar resistance to manage Fusarium head blight and deoxynivalenol in wheat. Plant Dis. 96:957-967.

Xue, S., Xu, F., Tang, M., Zhou, Y., Li, G., An, X., Lin, F., Xu, H., Jia, H., Zhang, L., Kong, Z., and Ma, Z. 2011. Precise mapping Fhb5, a major QTL conditioning resistance to Fusarium infection in bread wheat (Triticum aestivum L.). Theor. Appl. Genet. 123:1055-1063.

Ye, Z., Brûlé-Babel, A. L., Graf, R. J., Mohr, R., and Beres, B. L. 2017. The role of genetics, growth habit, and cultural practices in the mitigation of Fusarium head blight. Can. J. Plant Sci. 97:316-328.

Zhao, M., Wang, G., Leng, Y., Wanjugi, H., Xi, P., Grosz, M., Mergoum, M., and Zhong, S. 2018. Molecular mapping of Fusarium head blight resistance in the spring wheat line ND2710. Phytopathology 108:972-979. 